\title{
Influence of Sowing Date on Yields of Fresh-harvested Chickpea
}

\author{
Hana Badani \\ Agronomy and Natural Resources Department, Agricultural Research Organization \\ The Volcani Center, P.O.B. 6, Bet Dagan 50250, Israel \\ Ishay Katzir \\ Local experimental farm, Oshrat Mobile Post, 25252, Israel \\ David Shemesh \\ Extension Service and Field Crops Department, Ministry of Agriculture and Rural Development \\ Bet Dagan 50250, Israel \\ Gavriel Gera \\ Local experimental farm, Oshrat Mobile Post, 25252, Israel
}

Ran Hovav, Aharon Segev \& Shmuel Galili (Corresponding author)

Agronomy and Natural Resources Department, Agricultural Research Organization

The Volcani Center, P.O.B. 6, Bet Dagan 50250, Israel

Tel: 972-3-968-3872Ｅ-mail: galilis@agri.gov.il

\begin{abstract}
Chickpea is the main pulse crop in Israel, covering about 10000 ha. In order to increase the cultivation area of this crop, efforts have been made to develop agro-techniques for the fresh (immature green) harvesting chickpea. The objective of this study was to determine the effects of five sowing dates on the fresh and dry yields of two important Israeli chickpea cultivars, Zehavit and Bar. A field test conducted during the 2007-2008 winter season employed a split-plot design, in which the first and the second factors were sowing date and cultivar, respectively. The fresh yield, percentage of waste, expected fresh yield, intermediate dried yield and final dry yield were calculated for each plot. Cultivar Zehavit was superior to cv. Bar in terms of all of these parameters, except final dry yield. Thus, cv. Zehavit is the better cultivar for production of fresh-harvested chickpea, due to its ability to produce high yields of fresh seed with a lower percentage of waste. Our results indicate that some chickpea cultivars can be commercialized for production of the fresh-harvested crop in semi-arid climates.
\end{abstract}

Keywords: Expected fresh yield, Final dry yield, Fresh yield, Intermediate dried yield

\section{Introduction}

Chickpea (Cicer arietinum L.) is the second-most important pulse crop in the world and is grown in at least 37 countries in South and West Asia, North and East Africa, southern Europe, North and South America, and Australia. It covers $15 \%$ (11.6 million ha) of the area dedicated to pulse cultivation and accounts for $14 \%$ (7.6 million tons) of pulse production worldwide, making it second only to dry bean (FAOSTAT, 2008). In Israel, chickpea is the main pulse crop and is grown on about 7500 ha across the country, from the Negev in the south to the Galilee in the north, with average yields of 2-4 $\mathrm{T} \mathrm{ha}^{-1}$. Chickpea in Israel is mainly cooked and mashed into a paste (hummus) or deep-fried into falafel balls, both favorite dishes in the Israeli kitchen.

Similar to pea (Peksen et al., 2004; Santalla et al., 2001), chickpea is grown as a dry pulse crop or as a green vegetable (green chickpea), with the former being most common (Duke, 1981; Singh, 1985). Fresh green chickpea seeds are rich in protein, dietary fiber, folic acid, vitamin C, and minerals (Galili, Kitain, \& Badani, 2008) and resemble fresh soybean (edamame), fresh pea (Cousin, 1997), fresh faba bean (Bozoglu et al.,2002), and cowpea ( Peksen et al., 2002). As compared with dry chickpea, green chickpea might also contain lower 
levels of trypsin inhibitors and raffinose-family oligosaccharides, which accumulate only during seed desiccation (Obendorf et al, 1998) and are known to cause flatulence (Hata et al.,1991; Suarez et al., 1999). Green chickpeas do not need to be pre-soaked and require short cooking times, if any. These minimal cooking times allow the preservation of their nutritional quality ( Galili et al., 2008). Green chickpea seeds can be used to prepare falafel and hummus, can be sold as fresh produce, and can be pickled.

Fresh-harvested chickpea has a shorter growing period than dry-harvested chickpea, which saves up to about 1 $000 \mathrm{~m}^{3} \mathrm{ha}^{-1}$ water, and enables growers to use the field for an additional summer crop. These two traits are economically important in Israel. Thus in the last two years, in order to increase the amount of land planted to this crop, efforts have been made to develop agro-techniques for the harvesting of immature, green chickpea. Sandhu et al., (2007) performed field experiments to evaluate the green seed biomass of two very early chickpea varieties planted at different sowing dates and at different spacings. With respect to the regular cultivar, they showed that early flowering and podding cultivars had significantly higher green yields. However, in their experiment, fresh yield was measured at 75 days after sowing, at which point yields were far below those expected for late maturing chickpea crops.

The objective of this study was to determine the effects of different sowing dates on the fresh and dry yields of two important late maturing and high yielding Israeli chickpea cultivars. We show that one of the cultivars (Zehavit) is better for production of high-yielding fresh-harvested chickpea, due to its ability to produce high yields of fresh seed with a lower percentage of waste.

\section{Materials and Methods}

To examine the effects of five different sowing dates (Table 1) on yields of fresh-harvested chickpea (cvs. Zehavit and Bar), a field test was conducted during the 2007-2008 winter season at an experimental farm near Acre, Israel $\left(32^{\circ} 55^{\prime} \mathrm{N}, 35^{\circ} 04^{\prime} \mathrm{E}\right)$. The field site is characterized by black, heavy soil, an average annual rainfall of about 550-600 $\mathrm{mm}$, and average annual temperatures of 16 to $25^{\circ} \mathrm{C}$.

The field test employed a split-plot design with six replicates, in which the first and the second factors were sowing date and cultivar, respectively. Each plot consisted of two rows, $10 \mathrm{~m}$ long along a ridge, with $75 \mathrm{~cm}$ between rows and $5 \mathrm{~cm}$ between plants within each row. The plots were treated with $200 \mathrm{~kg} \mathrm{ha}^{-1}$ super phosphate, $200 \mathrm{~kg} \mathrm{ha}^{-1}$ potassium chloride, and $100 \mathrm{~kg} \mathrm{ha}^{-1}$ ammonium sulfate. Additionally, at the end of the growing season, water (950-1900 $\left.\mathrm{m}^{3} \mathrm{ha}^{-1}\right)$ was applied to the plots.

For pre-emergence weed control, $3 \mathrm{~L} \mathrm{ha}^{-1}$ Terbotraex (50\% terbutryne, Agan) was applied to the plots. During the growing season, the experiment was treated with $3 \mathrm{~L} \mathrm{ha}^{-1}$ Tionex (35\% endosulfan, Machteshim) to control insects, $0.5 \mathrm{~L} \mathrm{ha}^{-1}$ Signum (6.7\% pyraclostrobin $+26.7 \%$ boscalid, Agan) to control Ascochyta blight, and $4 \mathrm{~L} \mathrm{ha}^{-1}$ Kenon (78\% potassium phosphite, Luxembourg) to control Peronospora. To determine fresh-seed yield, each plot was manually harvested twice $\left(2 \mathrm{~m}^{2}\right.$ each) according to the growth stage of the crop (Table 1$)$. Harvested plants were threshed in a special apparatus that mimics a fresh pea combine. After threshing, fresh seeds were separated from unthreshed pods and other waste. These materials were then weighed separately, to determine fresh-seed and waste weights for each plot. Plot fresh yield $\left(\mathrm{T} \mathrm{ha}^{-1}\right)$ was calculated as:

(1) plot fresh yield $=\mathrm{A} * 5$,

where A is sample fresh seed weight $(\mathrm{kg})$.

The percentage of waste was calculated as:

(2) percentage of waste $=(B / A+B) * 100$,

where B is sample waste weight $(\mathrm{kg})$ and A is sample fresh seed weight $(\mathrm{kg})$. Unthreshed pods of each sample were then separated from the other waste, manually threshed, and weighed to determine the weight of the unthreshed seeds. Expected fresh yield (T ha-1) was calculated as:

(3) expected fresh yield $=(\mathrm{A}+\mathrm{C}) * 5$,

where A is sample fresh seed weight $(\mathrm{kg})$ and $\mathrm{C}$ is unthreshed seed weight $(\mathrm{kg})$. Samples of fresh seeds were dried in an oven at $65 \mathrm{oC}$ for $72 \mathrm{~h}$ to determine seed dry weight percentages. Plot intermediate dried yield (T ha-1) was calculated as:

(4) plot intermediate dried yield $=\mathrm{D} * \mathrm{E}$,

where $\mathrm{D}$ is expected fresh yield (T ha-1) and $\mathrm{E}$ is the percentage of seed dry weight. At the end of the experiment, the rest of each plot $(16 \mathrm{~m} 2)$ was harvested using a 140 Hege experimental combine and the final dry yield of each plot (T ha-1) was calculated as: 
(5) final dry yield of each plot $=\mathrm{F} * 0.625$,

where $\mathrm{F}$ is plot dry seed weight $(\mathrm{kg})$. Data were analyzed by ANOVA using the general linear model (GLM) procedure of the JMP 5 software (JMP, Version 5. SAS Institute, Inc. Cary, NC, 1989-2007). Comparisons between treatments (sowing dates/cultivars) were made using t-test analyses with the Tukey-Kramer honest significant range correction.

\section{Results and Discussion}

\subsection{Waste percentage}

The effects of sowing date on the waste percentages, fresh yields, expected fresh yields, intermediate dry yields, and final dry yields of two Israeli commercial cultivars are shown in Table 1. Waste percentages for cv. Zehavit ranged from 17 to $28 \%$ and, in most cases, were significantly lower than those observed for cv. Bar (19-38\%). A similar waste percentage of about $25 \%$ was observed in a 3-ha pilot experiment in cv. Zehavit, which was harvested using a fresh pea combine (Galili, unpublished results). This might be due to the fact that the pods of cv. Zehavit crack easily. In both cultivars, waste percentages were significantly higher in plots sown in November and February than in those sown during December and January (Table 2). Similar waste percentages (about 24\%) are found when edamame is harvested using a fresh bean apparatus (Born, 2006). In an experiment comparing the performance of different combines, Kee et al. (2004) found that waste percentages for garden pea ranged from $4-34 \%$. They also found the waste percentage in less tender peas was more than double that measured in young, tender peas.

\subsection{Fresh seed yield}

Fresh yields ranged from 3.2 to $6.5 \mathrm{~T} \mathrm{ha}^{-1}$ in the 'Zehavit' plots and from 1.9 to $4.9 \mathrm{~T}^{-1}$ in the 'Bar' plots (Table 1). Overall, the fresh yield of cv. Zehavit (average fresh yield of $5.2 \mathrm{~T} \mathrm{ha}^{-1}$ ) was significantly greater than that of $\mathrm{cv}$. Bar $\left(3.5 \mathrm{~T} \mathrm{ha}^{-1}\right)$ (Table 3). These results verify our previous finding that $\mathrm{cv}$. Zehavit is the better cultivar for fresh-harvested chickpea production in Israel. In most cases and as expected, the fresh yield at the second harvest was higher than that at the first harvest (Table 1). Our results of fresh chickpea yields resembled those of fresh pea (Peksen et al., 2004) and fresh faba bean (Jarso \& Keneni, 2006), but were lower than those of fresh soybean (Rao et al., 2002).

The best sowing dates were 30 December and 16 January, for which we observed average fresh yields of 5.4 and 5.1 $\mathrm{T} \mathrm{ha}^{-1}$, respectively. These were significantly greater than the fresh yield figures for the plots sown on 4 December, 11 February, and 11 November (Table 2). As mentioned above, Sandhu et al. (2007) evaluated the green seed biomass of two very early chickpea varieties at different sowing dates and spacing. The fresh yield was measured at 75 days after sowing, with yields of 1.8-2.0. Among other factors, such as cultivar and environmental differences, our higher green yields reflect the fact that, in the present study, green fresh weight was measured at the approximate time that commercial growers would harvest these two cultivars (between 97 and 169 days after sowing). Similar observations were obtained for expected fresh yield data (Tables 1-3 ). Sowing on 30 December and 16 January also resulted in an optimal harvesting period, 10-30 May. In Israel, this is the optimal time for the food companies to receive and process fresh seeds.

\subsection{Dry seed yield}

Chickpea plants, in contrast to green pea, have a non-determinant growth habit (van Rheenen et al., 1994). Thus, the crop should be harvested as late as possible, in order to maximize yields, but before the older seeds become yellowish, at which point the quality of the fresh seeds is reduced. In soybean, this stage is referred to as R6 (Fehr et al., 1971). Therefore, cultivars suitable for the production of fresh seeds should have concentrated yields (produce greater quantities of fully developed fresh seeds at a particular harvesting date). This requirement is of significant economic importance in Israel. In Israel, chickpeas are generally grown for dry seed production. Farmers will grow fresh chickpea only if their income per unit area for the fresh chickpeas will be the same or greater than that expected for dry seeds.

Concentrating yield can be estimated as the percentage of the intermediate dry yield (the dry yield of the fresh harvested seeds) relative to the final dry yield. Intermediate and final dry yields of cvs. Zehavit and Bar are shown in Table 1. The intermediate dry yield for $\mathrm{cv}$. Zehavit ranged from 1.2 to $3.2 \mathrm{~T}^{-1} \mathrm{~h}^{-1}$, with an average of $2.2 \mathrm{~T} \mathrm{ha}^{-1}$, and was always significantly greater than that observed for $\mathrm{cv}$. Bar, whose intermediate dry yield ranged from 1 to $2.3 \mathrm{~T} \mathrm{ha}^{-1}$, with an average of $1.7 \mathrm{~T} \mathrm{ha}^{-1}$ (Tables 1 and 3). Intermediate dry yield was influenced by both the sowing and harvest dates. Significantly higher intermediate dry yield values were observed for the plots sown on 30 December and 16 January, as compared to those sown on 4 December, 11 February, and 11 November (Tables 1 and 2). As expected, significantly higher intermediate dry yield values were also obtained 
for cv. Zehavit at the second harvesting date. For cv. Bar, however, significantly higher intermediate dry yield values were obtained at the second harvesting date only for those plots sown on 4 December and 11 February (Table 1). Similar observations were obtained for percentages of intermediate dry yield (Tables 1-3). These results indicate that cv. Zehavit is much more yield-concentrated than $\mathrm{cv}$. Bar, and is thus better suited for fresh harvesting.

The final dry yield of cv. Zehavit ranged from 2.4 to 5.0, with an average of $3.7 \mathrm{~T} \mathrm{ha}^{-1}$, and was not significantly greater than that observed for cv. Bar, which ranged from 2.4 to 4.9 , with an average of $4.0 \mathrm{~T}^{-1}$ (Tables 1 and 3). Final dry yield was also significantly influenced by the sowing date. From highest- to lowest-yielding, the sowing dates were as follows: 16 January $>30$ December $>11$ February $>4$ December $>11$ November (Table 2).

Percentages of intermediate dry yield for cv. Zehavit ranged from 43-91\%, with an average of $62 \%$, and were always higher than those of cv. Bar, which ranged from $27-57 \%$, with an average of $43 \%$ (Tables 1 and 3 ). These results may explain the higher green yields observed in fresh soybean with about 80-85\% pod fill (R6 stage) (Born, 2006; Fehr et al., 1971; Rao et al., 2002). Significantly different percentages of intermediate dry yield were also observed for the different sowing dates. Sowing in December led to significantly higher percentages of intermediate dry yield than sowing in February (Table 2). These results indicate that cv. Zehavit is much more yield-concentrated than cv. Bar, and is thus better suited for fresh harvesting in Israel.

\section{References}

Born, H. (2006). Edamame: Vegetable soybean. [Online] Available: http://www.attra.ncat.org/attrapub /PDF/edamame.pdf:1-4.

Bozoglu, H., Peksen, A., Peksen, E., \& Gülümser, A. (2002). Determination of green pod yield and some pod characteristics of faba bean (Vicia faba L.) cultivar/lines grown in different row spacings. Acta Horticultura, 579, 347-350.

Cousin, R. (1997). Peas (Pisum sativum L.). Field Crop Research, 53, 111-130.

Duke, J. A. (1981). Handbook of legumes of world economic importance. New York: Plenum Press.

FAOSTAT. (2008). [Online] Available: http://faostat.fao.org/default.aspx.

Fehr, W. R., Caviness, C. E., Burmood, D. T., \& Pennington, J. S. (1971). Stage of development descriptions for soybeans, Glycine max (L.) Merrill. Crop Science, 11, 929-931.

Galili, S., Kitain, S., \& Badani, H. (2008). Developing new uses for chickpea emphasis on healthy food. Nir Vatelem 3 January 2008, 8-10.

Hata, Y., Yamamoto, M., \& Nakajima, K. (1991). Effects of soybean oligosaccharides on human digestive organs: Estimation of fifty percent effective dose and maximum non-effective dose based on diarrhea. Journal of Clinical and Biochemical Nutrition, 10, 135-144.

Jarso, M., \& Keneni, G. (2006). Vicia faba L. In M. Brink, \& G. Belay (Eds.), PROTA (Plant Resources of Tropical Africa / Ressources végétales de l'Afrique tropicale). Wageningen, Netherlands.

Kee, E., Everts, K., Glancey, J., \& Wooten, T. (2004). [Online] Available: http://ag.udel.edu/extension/vegprogram/pdf/vf-04.pdf).

Obendorf, R. L., Horbowicz, M., Dickerman, A. M., Brenac, P., \& Smith, M. E. (1998). Soluble oligosaccharides and galactosyl cyclitols in maturing soybean seeds in planta and in vitro. Crop Science, 38, 78-84.

Peksen, A., Peksen, E., \& Bozoglu, H. (2002). Effects of sowing dates on yield and quality of cowpea (Vigna unguiculata L. Walp.) genotypes grown in a greenhouse. Acta Horticultura, 579, 351-354.

Peksen, E., Peksen, A., Bozoglu, H., \& Gulumser, A. (2004). Comparison of fresh pod yield and pod-related characteristics in pea (Pisum sativum L.) cultivars sown in autumn and spring under Samsun ecological conditions. Turkish Journal of Agriculture and Forestry, 28, 363-370.

Rao, M. S. S., Bhagsari, A.S., \& Mohamed, A. I. (2002). Fresh green seed yield and seed nutritional traits of vegetable soybean genotypes. Crop Science, 42, 1950-1958.

Sandhu, J. S., Sekhon, H. S., Singh, G., Bains, T. S., Gupta, S. K., Kaur, A., Saxena, A. K., \& Sharma, S. (2007). Short duration chickpea (Cicer arietinum) for vegetable purposes. Indian Journal of Agricultural Science, 77, 639-641. 
Santalla, M., Amurrio, J. M., \& de Ron, A. M. (2001). Symbiotic interactions between Rhizobium leguminosarum strains and elite cultivars of Pisum sativum L. Journal of Agronomy and Crop Science, 187, 59-68.

Singh, U. (1985). Nutritional quality of chickpea (Cicer arietinum L.): Current status and future research needs. Plant Foods Human Nutrition, 35, 339-351.

Suarez, F. L., Springfield, J., Furne, J. K., Lohrmann, T. T., Kerr, P. S., \& Levitt, M. D. (1999). Gas production in humans ingesting a soybean flour derived from beans naturally low in oligosaccharides. American Journal of Clinical Nutrition, 69,135-139.

Van Rheenen, H. A., Pundir, R. P. S., \& Miranda, J. H. (1994). Induction and inheritance of determinate growth habit in chickpea (Cicer arietinum L.). Euphytica 78, 137-141.

Table 1. Fresh and dry yield parameters of two chickpea cultivars for different combinations of sowing and harvest dates. Differences between treatments are indicated by different letters $(p(F)<0.05)$

\begin{tabular}{|c|c|c|c|c|c|c|c|c|}
\hline Cultivar & $\begin{array}{c}\text { Sowing } \\
\text { date }\end{array}$ & $\begin{array}{c}\text { Harvest } \\
\text { date }\end{array}$ & $\begin{array}{l}\text { Waste } \\
(\%)\end{array}$ & $\begin{array}{c}\text { Fresh } \\
\text { yield } \\
\left(\mathrm{T} \mathrm{ha}^{-1}\right) \\
\end{array}$ & $\begin{array}{c}\text { Expected } \\
\text { fresh yield } \\
\left.(\mathrm{T} \mathrm{ha})^{-1}\right) \\
\end{array}$ & $\begin{array}{c}\text { Intermediate } \\
\text { dried yield ( } \mathrm{T} \\
\left.\mathrm{ha}^{-1}\right)\end{array}$ & $\begin{array}{c}\text { Intermediate } \\
\text { dried yield } \\
(\%) \\
\end{array}$ & $\begin{array}{c}\text { Final dry } \\
\text { yield } \\
\left(\mathrm{T} \mathrm{ha}^{-1}\right)\end{array}$ \\
\hline \multirow[t]{9}{*}{ Zehavit } & $11 / 11 / 2007$ & $29 / 4 / 2008$ & $28 \mathrm{bcd}$ & $3.2 \mathrm{ijk}$ & $4.0 \mathrm{fgh}$ & $1.7 \mathrm{gh}$ & $71 \mathrm{bc}$ & $2.4 \mathrm{~d}$ \\
\hline & \multirow[t]{2}{*}{$4 / 12 / 2007$} & $29 / 4 / 2008$ & $25 \mathrm{cde}$ & $4.8 \mathrm{efg}$ & $5.6 \mathrm{cde}$ & $1.8 \mathrm{fg}$ & 63 bcde & $2.9 \mathrm{~cd}$ \\
\hline & & $7 / 5 / 2008$ & 17 ef & $5.3 \mathrm{cdef}$ & $6.2 \mathrm{bc}$ & $2.7 \mathrm{bcd}$ & $91 \mathrm{a}$ & I \\
\hline & \multirow[t]{2}{*}{$30 / 12 / 2007$} & 7/5/2008 & ND & $5.8 \mathrm{abcd}$ & $7.3 \mathrm{ab}$ & $2.1 \mathrm{defg}$ & $58 \mathrm{cdef}$ & $3.7 \mathrm{bc}$ \\
\hline & & $14 / 5 / 2008$ & 20 ef & $6.3 \mathrm{ab}$ & $7.4 \mathrm{a}$ & $3.0 \mathrm{ab}$ & $83 a b$ & I \\
\hline & \multirow[t]{2}{*}{$16 / 1 / 2008$} & $14 / 5 / 2008$ & $18 \mathrm{f}$ & 5.5 bcde & $6.2 \mathrm{bc}$ & $2.1 \mathrm{efg}$ & $43 \mathrm{fgh}$ & $5.0 \mathrm{a}$ \\
\hline & & $21 / 5 / 2008$ & $22 \mathrm{cdef}$ & $6.5 \mathrm{a}$ & $7.7 \mathrm{a}$ & $3.2 \mathrm{ab}$ & 64 bcde & 1 \\
\hline & \multirow[t]{2}{*}{$11 / 2 / 2008$} & $21 / 5 / 2008$ & $28 \mathrm{bc}$ & 3.8 hij & $4.5 \mathrm{efg}$ & $1.2 \mathrm{hi}$ & $27 \mathrm{~h}$ & $4.5 \mathrm{ab}$ \\
\hline & & $29 / 5 / 2008$ & $28 \mathrm{bc}$ & $6.1 \mathrm{abc}$ & $7.5 \mathrm{a}$ & $2.7 \mathrm{abc}$ & 62 cde & I \\
\hline \multirow[t]{9}{*}{ Bar } & $11 / 11 / 2007$ & $29 / 4 / 2008$ & $33 \mathrm{ab}$ & $1.9 \mathrm{~m}$ & $2.3 \mathrm{i}$ & $1.0 \mathrm{i}$ & $40 \mathrm{fgh}$ & $2.4 \mathrm{~d}$ \\
\hline & \multirow[t]{2}{*}{$4 / 12 / 2007$} & $29 / 4 / 2008$ & $28 \mathrm{bcd}$ & $3.3 \mathrm{jk}$ & $3.8 \mathrm{gh}$ & $1.2 \mathrm{hi}$ & $33 \mathrm{gh}$ & $3.8 \mathrm{bc}$ \\
\hline & & $7 / 5 / 2008$ & $191 \mathrm{f}$ & $4.1 \mathrm{ghi}$ & $4.7 \mathrm{def}$ & $2.0 \mathrm{efg}$ & 52 cdefg & I \\
\hline & \multirow[t]{2}{*}{$30 / 12 / 2007$} & $7 / 5 / 2008$ & ND & $4.9 \mathrm{defg}$ & $6.1 \mathrm{bc}$ & $2.0 \mathrm{efg}$ & 42 efgh & $4.7 \mathrm{ab}$ \\
\hline & & $14 / 5 / 2008$ & 22 def & $4.6 \mathrm{fgh}$ & $5.4 \mathrm{cde}$ & $2.3 \mathrm{cdef}$ & 50 cdefg & I \\
\hline & \multirow[t]{2}{*}{$16 / 1 / 2008$} & $14 / 5 / 2008$ & $25 \mathrm{cde}$ & $4.4 \mathrm{fgh}$ & $5.4 \mathrm{cde}$ & $2.1 \mathrm{efg}$ & 43 efgh & $4.9 \mathrm{a}$ \\
\hline & & $21 / 5 / 2008$ & $27 \mathrm{bcd}$ & 3.8 hij & $4.8 \mathrm{def}$ & 2.3 cde & 48 defg & I \\
\hline & \multirow[t]{2}{*}{$11 / 2 / 2008$} & $21 / 5 / 2008$ & $38 \mathrm{a}$ & $2.5 \mathrm{kl}$ & $3.4 \mathrm{hi}$ & $1.1 \mathrm{i}$ & $27 \mathrm{~h}$ & $4.2 \mathrm{ab}$ \\
\hline & & $29 / 5 / 2008$ & $32 \mathrm{~b}$ & $4.4 \mathrm{gh}$ & $5.7 \mathrm{~cd}$ & $2.3 \mathrm{cde}$ & $57 \mathrm{cdef}$ & / \\
\hline
\end{tabular}


Table 2. General effect of sowing date on fresh and dry yields of chickpea. Differences between treatments are indicated by different letters $(\mathrm{p}(\mathrm{F})<0.05)$

\begin{tabular}{|c|c|c|c|c|c|c|}
\hline $\begin{array}{c}\text { Sowing } \\
\text { date }\end{array}$ & Waste (\%) & $\begin{array}{c}\text { Fresh yield } \\
\left(\mathrm{T} \mathrm{ha}^{-1}\right)\end{array}$ & $\begin{array}{c}\text { Expected } \\
\text { fresh yield } \\
\left(\mathrm{T} \mathrm{ha}^{-1}\right)\end{array}$ & $\begin{array}{c}\text { Intermediate } \\
\text { dried yield } \\
\left(\mathrm{T} \mathrm{ha}^{-1}\right)\end{array}$ & $\begin{array}{c}\text { Intermediate } \\
\text { dried yield } \\
(\%)\end{array}$ & $\begin{array}{c}\text { Final dry } \\
\text { yield } \\
\left(\mathrm{T} \mathrm{ha}^{-1}\right)\end{array}$ \\
\hline 11 Nov. & $30 \mathrm{a}$ & $2.6 \mathrm{c}$ & $3.2 \mathrm{~d}$ & $1.3 \mathrm{c}$ & $56 \mathrm{ab}$ & $2.4 \mathrm{~d}$ \\
\hline 4 Dec. & $22 \mathrm{~b}$ & $4.3 \mathrm{~b}$ & $5.0 \mathrm{c}$ & $1.9 \mathrm{~b}$ & $60 \mathrm{a}$ & $3.4 \mathrm{c}$ \\
\hline 30 Dec. & $21 \mathrm{~b}$ & $5.4 \mathrm{a}$ & $6.4 \mathrm{a}$ & $2.4 \mathrm{a}$ & $58 \mathrm{a}$ & $4.2 \mathrm{~b}$ \\
\hline 16 Jan. & $23 \mathrm{~b}$ & $5.1 \mathrm{a}$ & $6.0 \mathrm{ab}$ & $2.4 \mathrm{a}$ & $50 \mathrm{ab}$ & $4.9 \mathrm{a}$ \\
\hline 11 Feb. & $32 \mathrm{a}$ & $4.2 \mathrm{~b}$ & $5.3 \mathrm{bc}$ & $1.8 \mathrm{~b}$ & $43 \mathrm{~b}$ & $4.4 \mathrm{~b}$ \\
\hline
\end{tabular}

Table 3. General effect of chickpea cultivar on fresh and dry yield. Differences between treatments are indicated by different letters $(\mathrm{p}(\mathrm{F})<0.05)$

\begin{tabular}{|c|c|c|c|c|c|c|}
\hline Cultivar & Waste (\%) & $\begin{array}{c}\text { Fresh yield } \\
\left(\mathrm{T} \mathrm{ha} \mathrm{C}^{-1}\right)\end{array}$ & $\begin{array}{c}\text { Expected } \\
\text { fresh yield } \\
\left(\mathrm{T} \mathrm{ha}^{-1}\right)\end{array}$ & $\begin{array}{c}\text { Intermediate } \\
\text { dried yield } \\
\left(\mathrm{T} \mathrm{h} \mathrm{h}^{-1}\right)\end{array}$ & $\begin{array}{c}\text { Intermediate } \\
\text { dried yield } \\
(\%)\end{array}$ & $\begin{array}{c}\text { Final dry } \\
\text { yield } \\
\left(\mathrm{T} \mathrm{ha}^{-1}\right)\end{array}$ \\
\hline Bar & $28 \mathrm{a}$ & $3.5 \mathrm{~b}$ & $4.4 \mathrm{~b}$ & $1.7 \mathrm{~b}$ & $43 \mathrm{~b}$ & $4.0 \mathrm{a}$ \\
\hline Zehavit & $24 \mathrm{~b}$ & $5.2 \mathrm{a}$ & $6.1 \mathrm{a}$ & $2.2 \mathrm{a}$ & $62 \mathrm{a}$ & $3.7 \mathrm{~b}$ \\
\hline
\end{tabular}

